\title{
Estimate the Compound Growth Rate (CGR) of Area, Production and Productivity of Chick-pea in Bemetara District of Chhattisgarh
}

\author{
Shashank Sharma* and B. C. Jain \\ Department of Agricultural Economics, College of Agriculture, IGKV, Raipur, India \\ *Corresponding author
}

\section{A B S T R A C T}

Keywords

Compound growth

rate, area,

production,

productivity,

significant \& non-

significant

Article Info

Accepted:

15 June 2021

Available Online:

10 July 2021
The present study was carried out to estimate the compound growth rate of area, production \& productivity of chick-pea in Bemetara district of Chhattisgarh. The current study made use of secondary data on area, production \& productivity from 2009-10 to 2018-19 were collected from various government sources including the Directorate of Economics \& Statistics and Department of Agriculture etc. to estimate the compound growth rates in area, production and productivity of chickpea. To examine the growth rates in area, production and productivity of chick pea of Bemetara district for the period of 2009-10 to 2018-19 exponential form were estimated. It can be clearly seen that the area, production \& productivity of chick pea in Bemetara district registered positive growth rate. In context of area Bemetara district shows non-significant growth. In context of production Bemetara district shows significant growth. In context of productivity Bemetara district shows significant growth.

\section{Introduction}

In many developing countries, chick pea is a major source of protein, especially among the poorest segments of the population who depend on vegetable sources to meet their protein and energy needs. Chickpea is cultivated primarily as a rainfed crop in India in almost all parts of the country. Chickpea production was projected at around 11.23 million tonnes (mt) during 2017-18, which is 46 percent of the overall production of pulses $(23.95 \mathrm{mt})$ in India. Madhya Pradesh accounted for 36.37 percent of the total gram area and 45.54 percent of the country's total gram production in 2018-19, ranking first in both area and production.

In terms of area, Maharashtra (16.94 per cent) and Rajasthan (15.92 per cent) were next. The 
ten states of MP, Rajasthan, Maharashtra, Karnataka, UP, AP, Gujarat, Jharkhand, Chhattisgarh and Telangana accounted for more than $90 \%$ of the country's gram output during the reporting period. In Chhattisgarh, in 2018-2019, pulse crops were grown in a sizeable area of 70313 tonnes of total production. Chhattisgarh's most important pulse crops are Lathyrus, Pigeon Pea, Chickpea, Black Gram and Green Gram.

The Chick pea is the most significant pulse crop in the state of Chhattisgarh. It currently occupies an area of 33.09 thousand hectares, with production in Chhattisgarh of 34.55 thousand metric tonnes. Bemetara, Rajnandgaon, Kabirdham and Durg are the main districts for chick-pea cultivation.

\section{Materials and Methods}

\section{Method of enquiry and data collection}

The current study made use of secondary data on area, production \& productivity from 200910 to 2018-19 were collected from various government sources including the Directorate of Economics \& Statistics and Department of Agriculture etc. to estimate the compound growth rates in area, production and productivity of chickpea.

\section{Analytical tools}

\section{Computation of growth rate}

Annual compound growth rates in area, production and productivity of Chickpea was done in the study area and for Chhattisgarh state by fitting an exponential function of the following form.

$Y=\alpha \beta t$ $\log Y=\log \alpha+t \log \beta$

Where,

$\mathrm{Y}=$ Area, production \& productivity of Chickpea

$\alpha=$ Constant

$\beta=$ Regression coefficient

$\mathrm{t}=$ time in year

Compound growth rate $(\%)=($ Antilog $\beta$ 1)100.

\section{Results and Discussion}

To examine the growth rates in area, production and productivity of chick pea of Bemetara district for the period of 2009-10 to 2018-19 exponential form were estimated.

Growth rate in area, production and productivity of chick pea

Growth rate in area, production and productivity of chick pea for Bemetara district is presented in Table 3.1. It can be clearly seen from the table that the area, production \& productivity of chick pea in Bemetara district registered positive growth rate. In context of area Bemetara district shows non-significant growth. In context of production Bemetara district shows significant growth. In context of productivity Bemetara district shows significant growth.

Growth rate in area, production and productivity of chick pea for Bemetara district is presented in Table 3.1. It can be clearly seen from the table that the area, production \& productivity of chick pea in Bemetara district registered positive growth rate. 
Table.1 Compound Growth Rate of area, production and productivity of chick pea

\begin{tabular}{|c|c|c|c|c|}
\hline & & \multicolumn{3}{|c|}{ Compound Growth Rate } \\
\hline S. No & Region & Area & Production & Productivity \\
\hline 1. & Bemetara & 0.01 & $1.75^{*}$ & $1.73^{*}$ \\
\hline
\end{tabular}

Note- * Significant at $5 \%$ level of significance.

Table.2 Area, production and productivity of chick pea in Chhattisgarh

\begin{tabular}{|c|c|c|c|c|}
\hline S. No. & Year & Area (ha) & Production (qt) & Productivity (qt/ha) \\
\hline 1. & 2009 & 101459 & 98361 & 0.97 \\
\hline 2. & 2010 & 101151 & 96159 & 0.95 \\
\hline 3. & 2011 & 80201 & 86872 & 1.08 \\
\hline 4. & 2012 & 86689 & 105445 & 1.22 \\
\hline 5. & 2013 & 100680 & 84933 & 0.84 \\
\hline 6. & 2014 & 92710 & 100363 & 1.08 \\
\hline 7. & 2015 & 90315 & 68349 & 0.76 \\
\hline 8. & 2016 & 81596 & 104770 & 1.28 \\
\hline 9. & 2017 & 96223 & 106456 & 1.11 \\
\hline 10. & 2018 & 104235 & 127562 & 1.22 \\
\hline
\end{tabular}

Source: Directorate of Economics \& Statistics Ministry of Agriculture, Govt. of India.

Fig.1 Trend in area of chick pea in Bemetara district

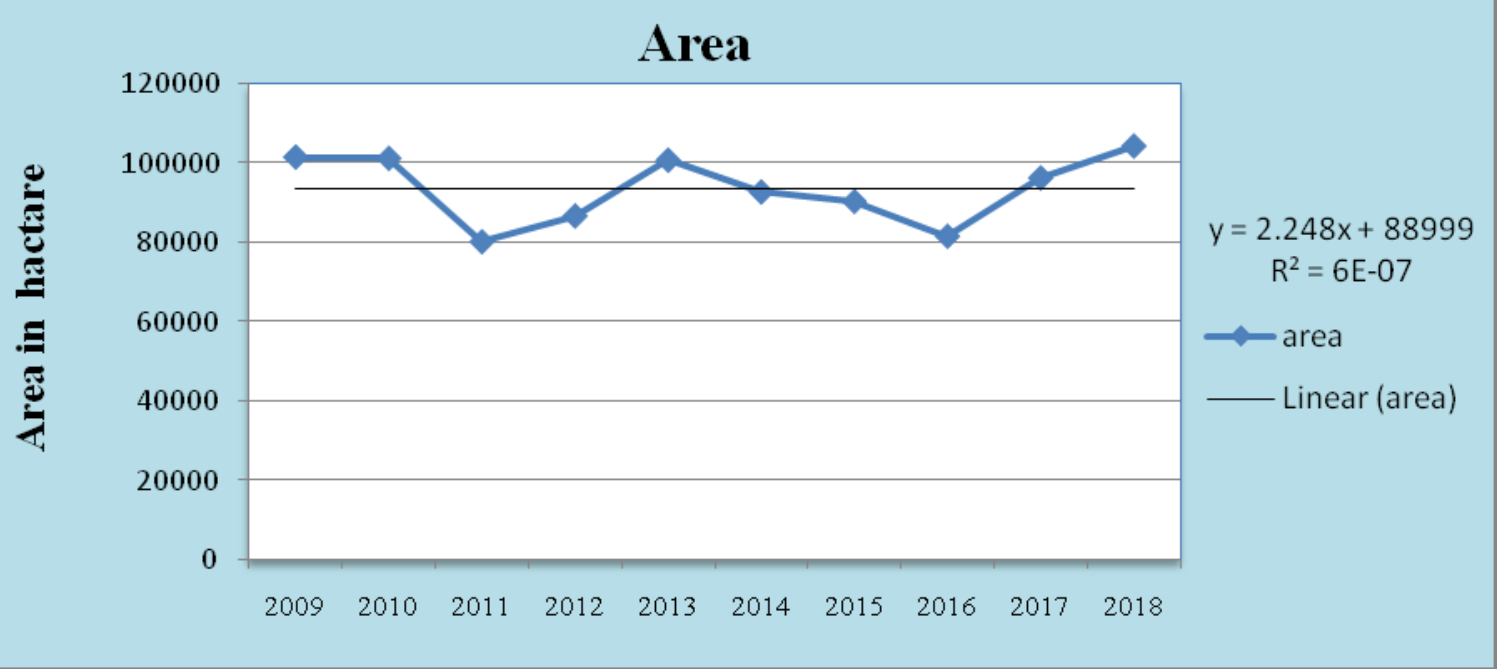


Fig.2 Trend in production of chick pea in Bemetara district

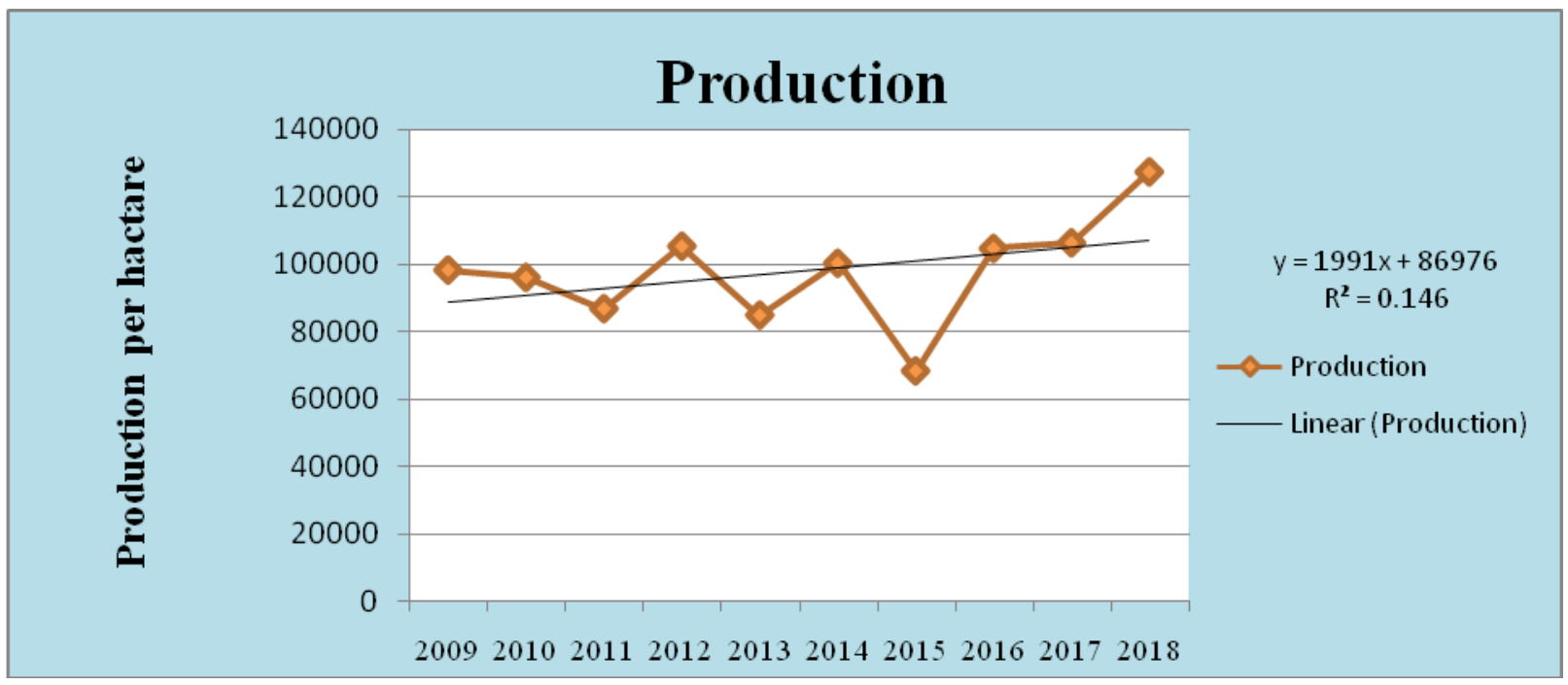

Fig.3 Trend in productivity of chick pea in Bemetara district

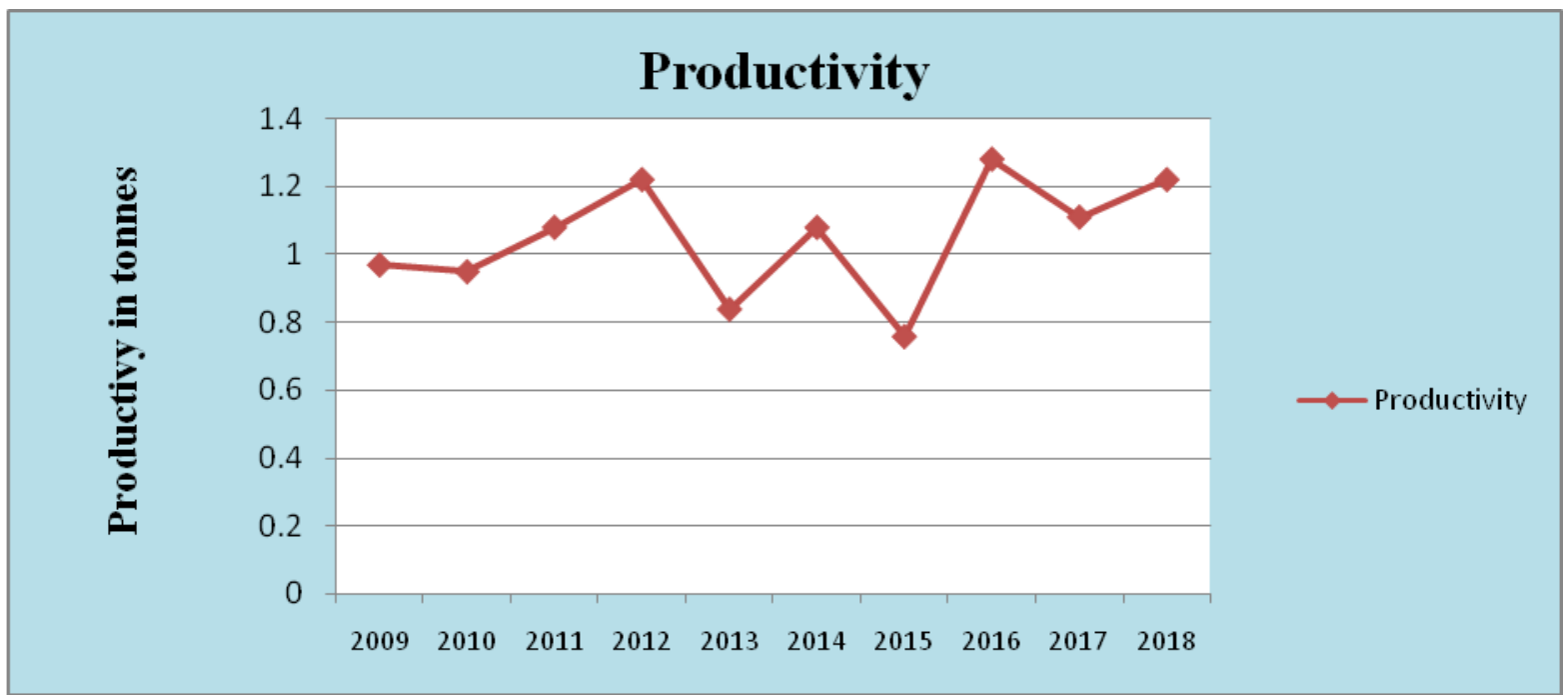

In context of area Bemetara district shows non-significant growth which is 0.01. In context of production Bemetara district shows significant growth which is 1.75 . In context of productivity Bemetara district shows significant growth which is 1.73 .

\section{References}

Arora, K. P. S.; S. K., Shrivastava and J. S. Baghel (1994). "Changing Agriculture Performance in Uttar Pradesh, A
Regional Analysis". Indian Journal of Agricultural Economics.52 (3): 463464.

Naik, Dibakar and Binod Ch., Mohanty (1991). An Anatomy of Production and Marketing of Groundnut Oil in Orissa. Indian Journal of Agril. Marketing,5(1):51-57.

Pratibha, G., Korwar, G. R., and Sharma, K. L. 2004. Production potential of different oilseed crops of farm evaluation. Journals of oilseeds 
research, 21(2): 322-324.

Salikram, 1993. Growth Analysis of Oilseed in Orissa State. Indian Journal of Agricultural Economics.48(3): 377378.

Shete, V. R.; J. R., Pawar and S. B. Dangat, (1997). "Growth Performance of Agriculture among The Different Regions in Maharastra". Indian Journal of Agricultural Economics.52 (3): 449450 .
Singh, D. V. and R. Swarup, (1988). Problem and prospects of pulses and oilseed production in Himachal Pradesh. Agro-Economic Research Centre, Himachal Pradesh University, Simla. 87.

Singh, G. and Chandra, H. (2004). Production and economic factors growth in cultivation of groundnut in India. Journal of Oilseeds Research, 21(1).

\section{How to cite this article:}

Shashank Sharma and Jain, B. C. 2021. Estimate the Compound Growth Rate (CGR) of Area, Production and Productivity of Chick-pea in Bemetara District of Chhattisgarh. Int.J.Curr.Microbiol.App.Sci. 10(07): 270-274. doi: https://doi.org/10.20546/ijcmas.2021.1007.028 